\title{
Prospects of Cooperative Society for Sustainable Agriculture Among Smallholder Farmers in Benue State, Nigeria
}

\author{
Attah Agbo Joseph ${ }^{1}$, Mbah Evangeline Nwakaego ${ }^{2, ~ *}$, Okeke Margaret Ngozi $^{3}$ \\ ${ }^{1}$ Department of Agricultural Extension and Rural Sociology, University of Abuja, Abuja, Nigeria \\ ${ }^{2}$ Department of Agricultural Extension and Communication, Federal University of Agriculture, Makurdi, Nigeria \\ ${ }^{3}$ Department of Agricultural Economics and Extension, Chukwuemeka Odumegwu Ojukwu University, Igbariam, Nigeria \\ Email address: \\ evanmbah@gmail.com (Mbah. E. N.) \\ ${ }^{*}$ Corresponding author
}

\section{To cite this article:}

Attah Agbo Joseph, Mbah Evangeline Nwakaego, Okeke Margaret Ngozi. Prospects of Cooperative Society for Sustainable Agriculture Among Smallholder Farmers in Benue State, Nigeria. International Journal of Applied Agricultural Sciences.

Vol. 4, No. 5, 2018, pp. 103-109. doi: 10.11648/j.ijaas.20180405.11

Received: September 15, 2018; Accepted: September 30, 2018; Published: November 14, 2018

\begin{abstract}
The study was conducted to ascertain prospects of cooperative society for sustainable agriculture among smallholder farmers in Benue state, Nigeria. Data were collected from eighty (80) respondents using questionnaire. Frequency, percentage, mean score and factor analysis were used for analyzing data collected for the study. Findings indicate that about $39 \%$ of the respondents were aged between 41 and 50 years while $7.5 \%$ were aged above 60 years, among others. A greater percentage $(63.8 \%)$ of the respondents were males with majority $(88.8 \%)$ being married, $40 \%$ of them acquired tertiary education with $50.0 \%$ having a household size of $1-5$ persons while $68.8 \%$ had farming as a major occupation. Savings and contributions $(57.0 \%)$ were major sources of fund for cooperative society. Major reasons for joining cooperative society were access to credit facilities (38.8\%), greater access to farm inputs $(26.2 \%)$, raise standard of living $(11.2 \%)$, among others. Results on benefits of cooperatives society include access to information (94.5\%), increases members income and food security $(91.8 \%)$, high productivity/ increase in output $(90.4 \%)$, easy access to loan facilities $(89.0 \%)$, improved market competition and expanded market opportunities $(89.0 \%)$, pulling of resources together (86.3\%), easy access to credit facilities $(80.8 \%)$, greater access to farm inputs $(75.3 \%)$, availability of labour $(61.5 \%)$, etc. Factors influencing performance of cooperative society were named institutional, funding and input- related variables. The study recommends that there is need for timely provision of farm inputs for the farmers in order to increase productivity for sustainable agriculture. Adequate awareness campaign is needed in ensuring that farmers become members of cooperative society so as to pull their resources together for greater productivity.
\end{abstract}

Keywords: Prospects, Cooperative Society, Sustainable, Agriculture, Smallholder Farmers, Nigeria

\section{Introduction}

One of the major problems of agricultural development in Nigeria is that of developing appropriate organization and institution to mobilize members of the rural sector to a greater productive effort [1]. Rural farmers who are characterized by low income, low resource utilization, small farm holdings and scattered nature of farmland find it difficult to pool their resources together in order to raise their farm income and substantially improve their living conditions. In such situation, cooperatives represent a strong and viable economic alternative. International Cooperative Alliance (2010) defines cooperative society as an autonomous association of persons unified voluntarily to meet their common economic, social and cultural needs through a jointly-owned and democratically controlled enterprise. It is a business voluntarily owned and controlled by its member patrons and operates for them and by them on a non-profit basis. It is also a business enterprise that aims at 
complete identity of the component factors of ownership control and use of services [2].

Cooperative societies are very common in Nigeria. There are traditional and modern cooperative societies. The modern cooperative societies started in the country as a result of the Nigerian cooperative society law enacted in 1935 following the report submitted by C. F. Strickland in 1934 to the then British colonial administration on the possibility of introducing cooperatives into Nigeria [3].

Cooperatives societies in Nigeria like their counterparts all over the world are formed to meet people's mutual needs. Cooperatives are considered useful mechanism to manage risks for member in agriculture. Cooperatives enable farmers to pool their limited resources together to improve agricultural outputs which enhance socio-economic activities in the rural areas [4].

Arua (2004) viewed cooperative society as an important tool for improving the living conditions of farmers. They participate in decision making process, identification of farmers' needs, input service delivery, farmers' education, financing, contracting, warehousing, processing, packaging and advertising of farm products, among others. Cooperative societies serve as avenues for input distribution. They have developed strong and reliable arrangements for the distribution of food crops, fertilizers, agro-chemicals, credits, seeds and seedlings. Cooperatives played an important role in mobilizing and distributing credit to the farmers. He further stressed that cooperatives provide members with a wide range of services such as credit, health, recreational and housing facilities. Agricultural cooperatives are also useful in the dissemination of information about modern practice in agriculture [2].

Cooperative societies in Nigeria perform multi-purpose functions. They are engaged in the production, processing, marketing, distribution and financing of agricultural products [5]. The most popular agricultural cooperative societies available in Benue State, Nigeria include group farming cooperative, marketing cooperative, agricultural thrift and credit cooperative, agricultural processing cooperative, consumer cooperative, fishery cooperative and farmers' multi-purpose cooperative. Rural farmers in Benue state like their counterparts in other parts of Nigeria are trapped in perpetual poverty and malnutrition. Hence, there is need for farmers to form cooperative societies to allow them pool their resources together for increased agricultural productivity [5].

According to Borgens [6], the most important reasons for cooperative society failure in Nigeria include shortage of trained managers, lack of understanding of the principles and approaches of cooperative society and inability of cooperative members to cope with the modern methods and tools of production. Cooperative society serves as an effective community development vehicle by their nature they build economic self reliance and civil society. The benefits of cooperative society accrue to the larger society because they create local jobs, re invest locally, emphasis on education and skills raises local management capacity, reduce migration and concentration of capital. People come together in cooperative societies to pool their resources together so as to meet individual needs that could not be resolved by individual limited financial capacity [7]. The aim of cooperative societies is to produce goods and deliver services, and satisfy the legitimate needs of members and also to promote cooperation, relations, participation and consequently to promote interpersonal connections. Cooperative societies provide services that benefit both members and the local community. It was also observed that it is an essential tool for development of less economically developed communities [8].

Employment opportunities are provided by cooperative society to the teeming population of the rural populace which helped greatly towards socio-economic development of both urban and rural areas [8]. Cooperative society serves as useful instruments for marketing farmers' produce and as avenues for saving and credit facilities as these informal financial institutions are mostly preferred by Farmers due to easy accessibility, smallness of scale, and informal nature of transactions [9]. They play a significant role in provision of services that enhances agricultural development. Flannery described cooperative societies as a medium through which services like provision of farm inputs, farm implements, farm mechanization, agricultural loans, agricultural extension, members' education, marketing of members' farm produce and other economic activities and services rendered to members [10].

Majority of Benue state indigenes depend on small-scale subsistence agriculture for their livelihoods. These smallscale farmers face numerous challenges among which are inadequate education which precludes access to markets or bargaining on prices, soil erosion which sweeps away both fertile soil and planted crops during rainy season and lack of mechanization which leaves smallholders reliant on rainfall. In addition, high population density inversely reduces land per household which in turn reduces agricultural production.

According to Onuoha, cooperative society's programmes in developing countries have always suffered from content deficiency [3]. For instance, due considerations have never been given to adult and non-formal education by these cooperative societies, as a tool for empowering people against poverty [11]. Inadequate government support to cooperative society has been a major setback for effective performance. Attention given to the cooperative societies by the Nigerian government is not enough to cater for the ever increasing number of the societies. It is more of rhetoric's than actual action which greatly affects the activities of the societies [12].

This therefore raises the following questions. What are the socio-economic characteristics of the respondents? What are the sources of funds for cooperative society? What are types of activities carried out by cooperative society? What are the benefits of cooperative society? What are the factors influencing the performance of cooperative society?

The specific objectives were to: 
i. describe socio-economic characteristics of the respondents;

ii. ascertain sources of funds for cooperative society;

iii. identify types of activities carried out by cooperative society;

iv. ascertain benefits of cooperative society; and

v. identify factors influencing the performance of cooperative society.

\section{Methods}

\subsection{The Study Area}

The study was carried out in Benue State, Nigeria. The state is located in the middle belt region of Nigeria. Benue State is delineated into three agricultural zones, namely; zone A (Logo, Ukum, Kastina-Ala, Vandeikya, Konshisha, Kwande and Ushongo), Zone B (Makurdi, Guma, Gwer East, Gwer West, Gboko, Tarka and Buruku) and Zone C (Ado, Agatu, Apa, Obi, Ogbadibo, Ohimini, Oju, Okpokwu and Otukpo). The state comprises a total of 23 Local Government Areas with Makurdi as the state capital. It has an estimated population of 4,219,244 people [13]. The state shares boundaries with five other states namely; Nasarawa State to the north, Taraba State to the east, Cross-River State to the south, Enugu State to the south-west and Kogi State to the west. The state also shares a common boundary with the Republic of Cameroon on the south-east. It occupies a landmass of 34,059 square kilometers.

Benue State has two main seasons; the wet (rainy) and the dry season. The rainy season starts usually in April and ends in October with its peak in May and September while the dry season starts in November and ends in March. Farming is the predominant occupation of the people of Benue State with over $80 \%$ engaged in it. Major crops grown are rice, groundnut, cowpea, cassava, sweet potato, maize and sorghum. Tree crops grown include citrus, mango, oil palm, cashew and guava. Cattle, sheep, goat, pig, rabbits and poultry are livestock raised in the state. The people in the state also engage in non-farm activities such as trading, civil service among others. The inhabitants of this state are mainly the Tivs, Idomas, Igedes, Jukuns and other ethnic groups.

\subsection{Population and Sample Size of the Study}

The population of the study consisted of all smallholder farmers who are members of cooperative society. Zone B was selected purposively from the three agricultural zones in the state. Two local government areas were selected from the zone using simple random sampling technique. In each of the local government areas, two communities were selected. Twenty (20) respondents who are members of cooperative society were selected from each of the communities, giving a total of eighty (80) respondents used for the study.

\subsection{Method of Data Collection}

Questionnaire was used to collect data for the study. The questionnaire was divided into five sections, namely; A, B,
C, D and E. Section A focused on socio-economic characteristics of the respondents. Section B centered on sources of funds for cooperative society. Section $\mathrm{C}$ addressed types of activities carried out by cooperative society. Section $\mathrm{D}$ centered on benefits of cooperative society while section $\mathrm{E}$ dwelt on the factors influencing the performance of cooperative society.

\subsection{Data Analysis Techniques}

Data were analyzed using descriptive statistics which include frequency, percentage, mean score as well as inferential statistic such as factor analysis. Objectives 1, 2, 3 and 4 were analyzed using frequency, percentage and mean score while objective 5 was analyzed using factor analysis.

\section{Results and Discussion}

\section{Socioeconomic Characteristics of the Respondents Age}

Table 1 show that $38.8 \%$ of the respondents were aged 41 50 years while $7.5 \%$ were within the age range of above 60 years, among others. The mean age was 45.5 years. This implies that the respondents were middle-aged, productive and in their active years. Age is also positively correlated with productivity as older farmers have also been observed to have higher productivity than younger farmers as a result of experiences acquired over the years.

Sex

Majority $(63.8 \%)$ of the respondents were males (Table 1$)$. This implies that males were more involved in agricultural production in the study area. This could be due to the sociocultural milieu of the area which gives males access to production resources such as land which is a requirement for production.

\section{Marital status}

Entries in Table 1 show that majority (88.8\%) of the respondents were married while $6.2 \%$ were single. This implies that there were more married individuals in farming in the area. This is in line with the findings of Ajani who stated that farming activities are done mostly by people who are married and are responsible enough to take family decisions [14].

Level of education

Results in Table 1 indicate that $40.0 \%$ of the respondents had tertiary education, $28.8 \%$ had primary education, among others. This implies that majority of the respondents were literate as they attained one form of education or the other. Education however, is one of the key assets needed to foster productivity in any profession. This is likely because higher education propels heads of farming households to adopt innovations and new technologies that are vital for enhancing farm productivity and improved economic status. It therefore suggests that increase in education will enhance participation in cooperative society as it provides better understanding of the modalities for obtaining credits.

Household size

A greater percentage $(50.0 \%)$ of the respondents had 
household size of 1-5 persons, $6.2 \%$ had household size of between 11 and 15 persons, among others (Table 1). This indicates that most of the farmers have quite large household size which means greater responsibility. This has made them to be members of cooperative society in order to have access to production resources. However, large household size has been identified in some areas to be detrimental to productivity. The higher the dependency ratio, the lower will be the farming household productivity.

Farming experience

Entries in Table 1 indicate that $37.5 \%$ of the respondents had between 6 and 10 years of experience, $12.5 \%$ had 11-15 years of farming experience, among others. The mean farming experience was 14 years. This implies that most cooperative society members have acquired reasonable years of experience in farming which have positive effects on agricultural production. Indeed, experience goes a long way in skill acquisition which is fundamental to efficiency and effectiveness in any job operation.

Farm size

Majority $(81.2 \%)$ of the respondents had farm size of $1-5$ hectares, $16.2 \%$ had farm size of 6-10 hectares, among others (Table 1). This suggests that majority of the respondents practiced farming at a subsistence level. They are farmers whose average land holdings is about 1-3 hectares who cannot benefit from economies of scale hence resort to cooperative societies. This buttresses Ajani and Agwu who stated that both the young and aged still produce at the subsistence level in order to feed members of their families [15].

\section{Annual farm income}

Results in Table 1 indicate that most (42.5\%) of the respondents earned $<\$ 250,000$, about $11.2 \%$ earned above $\$ 750,000$, among others. The mean annual income was $\$ 372,462.50$. This implies that the respondents had relatively large sum of money from farming. This may be attributed to the fact that they were members of cooperative society who have pooled their resources together for enhanced productivity. The income generated by the cooperatives members have played vital role in rural and agricultural development since all the cooperatives societies are fully engaged in agricultural activities [16].

\section{Primary occupation}

Majority (68.8\%) of the respondents had farming as a major occupation, $20 \%$ were civil servants, among others (Table 1). This finding agrees with Ajani who observed that most of the people in the rural areas are engaged in subsistence farming [17].

\section{Extension contact}

About $81 \%$ of the respondents had contact with extension agents (Table 1). This implies that the respondents had contact with extension agents which equip them with managerial skill, on improved production technologies. This finding agrees with Mbah, Ezeano and Onwusika who reported that contact with extension agents motivates and exposes the farmers to innovations [18].
Table 1. Distribution of Respondents according to Socio-economic Characteristics $(n=80)$.

\begin{tabular}{|c|c|c|c|}
\hline $\begin{array}{l}\text { Socio-economic } \\
\text { Characteristics }\end{array}$ & Frequency & Percentage & Mean Score \\
\hline \multicolumn{4}{|l|}{ Age (years) } \\
\hline $21-30$ & 7 & 8.8 & \\
\hline $31-40$ & 20 & 25.0 & \\
\hline $41-50$ & 31 & 38.8 & \\
\hline $51-60$ & 16 & 20.0 & \\
\hline Above 60 & 6 & 7.5 & 45.5 \\
\hline \multicolumn{4}{|l|}{ Sex } \\
\hline Male & 51 & 63.8 & \\
\hline Female & 29 & 36.2 & \\
\hline \multicolumn{4}{|l|}{ Marital status } \\
\hline Married & 63 & 88.8 & \\
\hline Single & 17 & 11.2 & \\
\hline \multicolumn{4}{|l|}{ Level of education } \\
\hline Primary & 23 & 28.8 & \\
\hline Secondary & 25 & 31.2 & \\
\hline Tertiary & 32 & 40.0 & \\
\hline \multicolumn{4}{|l|}{$\begin{array}{l}\text { Household size } \\
\text { (numbers) }\end{array}$} \\
\hline $1-5$ & 40 & 50.0 & \\
\hline $6-10$ & 35 & 43.8 & \\
\hline $11-15$ & 5 & 6.2 & \\
\hline \multicolumn{4}{|l|}{$\begin{array}{l}\text { Farming } \\
\text { experience (years) }\end{array}$} \\
\hline $1-5$ & 13 & 16.2 & \\
\hline $6-10$ & 30 & 37.5 & \\
\hline $11-15$ & 10 & 12.5 & \\
\hline $16-20$ & 15 & 18.8 & \\
\hline Above 20 & 12 & 15.0 & 13.6 \\
\hline \multicolumn{4}{|l|}{$\begin{array}{l}\text { Farm size } \\
\text { (hectares) }\end{array}$} \\
\hline $1-5$ & 65 & 81.2 & \\
\hline $6-10$ & 13 & 16.2 & \\
\hline Above 10 & 2 & 2.5 & \\
\hline \multicolumn{4}{|l|}{$\begin{array}{l}\text { Annual farm } \\
\text { income (Naira) }\end{array}$} \\
\hline$<250,000$ & 34 & 42.5 & \\
\hline $250,000-500,000$ & 23 & 28.8 & \\
\hline $500,001-750,000$ & 14 & 17.5 & \\
\hline $750,001-1,000,000$ & 9 & 11.2 & $372,462.50$ \\
\hline \multicolumn{4}{|l|}{$\begin{array}{l}\text { Primary } \\
\text { occupation }\end{array}$} \\
\hline Farming & 55 & 68.8 & \\
\hline Civil service & 16 & 20.0 & \\
\hline Trading & 8 & 10.0 & \\
\hline Others & 1 & 1.2 & \\
\hline \multicolumn{4}{|l|}{ Extension contact } \\
\hline Yes & 65 & 81.2 & \\
\hline No & 15 & 18.8 & \\
\hline
\end{tabular}

\section{Sources of Fund for Cooperative Society}

Sources of fund for cooperative society include savings and contributions $(57.0 \%)$, cooperatives $(16.5 \%)$, relations (11.4\%), bank loan (8.9\%), credit purchasing (5.1\%) and donor funding $(2.5 \%)$ (Table 2$)$. This implies that personal savings and contributions of members of cooperative serve as major sources of fund. Onogwu and Arene observed that low level of income and savings among smallholder farmers in Nigeria, impose limitations on the availability of adequate equity capital for financing smallholder agriculture [19]. They further argued that the remoteness of microfinance institutes to smallholder farmers in critical need of credit and 
the cumbersome lending procedures further affects their accessibility to credit.

Table 2. Distribution of Respondents according to Sources of Fund ( $n=80)$.

\begin{tabular}{lll}
\hline Sources of Fund* & Frequency & Percentage \\
\hline Savings and contributions & 45 & 57.0 \\
Bank loan & 7 & 8.9 \\
Credit Purchasing & 4 & 5.1 \\
Donor funding & 2 & 2.5 \\
Cooperatives & 13 & 16.5 \\
Relations & 9 & 11.4 \\
\hline
\end{tabular}

*Multiple responses

\section{Major Reasons for Joining Cooperative Societies}

Results in Table 3 indicate major reasons for joining cooperative society which include access to credit facilities $(38.8 \%)$, greater access to farm inputs $(26.2 \%)$, raise standard of living $(11.2 \%)$, increase in income $(10.0 \%)$, improving production $(8.8 \%)$ and employment opportunities $(5.0 \%)$. This finding corroborates that of Ekong who reported that farmers joined cooperative societies because members are assumed to have more access to credit facilities, farm inputs, raise standard of living and improve production [20].

Table 3. Distribution of Respondents according to Major Reasons for Joining Cooperative Society $(n=80)$.

\begin{tabular}{lll}
\hline $\begin{array}{l}\text { Reasons for joining Cooperative } \\
\text { Society }\end{array}$ & Frequency & Percentage \\
\hline Access to credit facilities & 31 & 38.8 \\
Employment opportunities & 4 & 5.0 \\
Greater access to farm inputs & 21 & 26.2 \\
Improving production & 7 & 8.8 \\
Increase in income & 8 & 10.0 \\
Raise standard of living & 9 & 11.2 \\
\hline
\end{tabular}

Major Activity of Cooperative Society

Major activity of cooperative society include crop production (41.2\%), livestock keeping $(28.7 \%)$, marketing of farm produce $(16.2 \%)$, processing of crops $(5.0 \%)$, source of labour (5.0\%) and storage (3.8\%) (Table 4). This implies that crop production is the major activity carried out by most cooperative society in the study area.

Table 4. Distribution of Respondents According to Major Activity of Cooperative Society $(n=80)$.

\begin{tabular}{lll}
\hline Major activity of Cooperatives Society & Frequency & Percentage (\%) \\
\hline Crop production & 33 & 41.2 \\
Processing of crops & 4 & 5.0 \\
Marketing of farm produce & 13 & 16.2 \\
Storage & 3 & 3.8 \\
Source of labour & 4 & 5.0 \\
Livestock keeping & 23 & 28.7 \\
\hline
\end{tabular}

Benefits of Cooperative Society

Results in Table 5 indicate benefits of cooperatives society which include access to information (94.5\%), increases members income and food security (91.8\%), high productivity/ increase in output $(90.4 \%)$, easy access to loan facilities (89.0\%), improved market competition and expanded market opportunities $(89.0 \%)$, pulling of resources together $(86.3 \%)$, easy access to credit facilities $(80.8 \%)$, greater access to farm inputs $(75.3 \%)$, availability of labour $(61.5 \%)$, reduction in cost of production $(57.5 \%)$, easy access to training opportunities $(56.2 \%)$, increase in bargaining strength $(54.8 \%)$ and reduction in risks of production (52.1\%). This implies that respondents benefited from cooperative society as it empowers members economically and socially. According to Nweze, it also creates sustainable rural employment through business models that are resilient to economic and environmental shocks [21].

Table 5. Distribution of Respondents according to Benefits of Cooperative Society $(n=80)$

\begin{tabular}{lll}
\hline Benefits of Cooperative Society* & Frequency & Percentage \\
\hline Easy access to credit facilities & 59 & 80.8 \\
Reduction in cost of production & 42 & 57.5 \\
Availability of labour & 45 & 61.5 \\
Increase in bargaining strength & 40 & 54.8 \\
Pulling of resource together & 63 & 86.3 \\
High productivity/ increase in output & 66 & 90.4 \\
Reduction in risks of production & 38 & 52.1 \\
Easy access to training opportunities & 41 & 56.2 \\
Easy access to loan facilities & 65 & 89.0 \\
Greater access to farm inputs & 55 & 75.3 \\
Access to information & 69 & 94.5 \\
Increases members income and food & 67 & 91.8 \\
security & & \\
Improved market competition and & 65 & 89.0 \\
expanded market opportunities & 55 & 75.3 \\
Democratic support social cohesion & & \\
\hline *Multiple responses &
\end{tabular}

Factors Influencing Performance of Cooperative Society

Results of factor analysis of the factors influencing performance of cooperative society is presented in Table 6 . Three constraint factors were extracted based on the responses of the farmers namely; factor 1 (institutional factors), factor 2 (funding factors) and factor 3 (input- related factors).

Variables that loaded under factor 1(institutional factors) were poor management of resources (0.578), illiteracy of members (0.641), lack of cooperation among members (0.713), lack of commitment to responsibilities (0.746), insincerity and dishonesty (0.611), high fragmentation of land holdings (0.471), inadequate training opportunities (0.843), inadequate extension programmes (0.563) and inadequate public awareness (0.853). This implies that institutional factors were hampering the performance of cooperative society in the study area. This finding agrees with Nnadozie, Oyediran, Njoku and Okoli who opined that poor education and illiteracy of members, farmers' access to farm inputs, poor extension services and conflicts among members are challenges faced by members of the farmers' cooperative societies [16].

Funding factors include insufficient capital (0.672), misappropriation of funds (0.701), individualistic tendencies (0.697) and politics among members (0.680). This implies that funding factors hinders effective performance of cooperative society. This finding agrees with Ebonyi and 
Jimoh who also found out that lack of collateral, lack of guarantor, high interest rate and mode of payment were prominent among constraints impeding performance of cooperative society [22].

Variables that loaded in factor 3 (input-related factors) were insufficient number of members (0.523), lack of funds (0.773), untimely provision of farm inputs $(0.752)$ and inability of government to subsidize farm inputs (0.805). This implies that performance of cooperative society is also influenced by input related factors. This finding agrees with Muhammad who opined that challenges associated with agricultural cooperatives financing in Nigeria include lack of technological knowhow such as mechanized farming; poor implementation of government policies; lack of basic infrastructural facilities such as access road, electricity; inadequate training; high interest rate, among others [12].

Table 6. Factor Analysis of Factors Affecting Performance of Cooperative Society

\begin{tabular}{llll}
\hline Factors & Factor 1 & Factor 2 & Factor 3 \\
\hline Poor management of resources & $0.578^{*}$ & 0.183 & 0.303 \\
Illiteracy of members & $0.641^{*}$ & 0.077 & 0.270 \\
$\begin{array}{l}\text { Lack of cooperation among } \\
\text { members }\end{array}$ & $0.713^{*}$ & 0.204 & 0.255 \\
Lack of commitment to & & & \\
responsibilities & $0.746^{*}$ & 0.187 & 0.157 \\
Insincerity and dishonesty & $0.611^{*}$ & 0.051 & 0.102 \\
Improper planning activities & 0.453 & 0.408 & 0.129 \\
Overdue loans & -0.012 & 0.246 & 0.117 \\
Insufficient capital & 0.289 & $0.672 *$ & 0.174 \\
Misappropriation of funds & 0.210 & $0.701 *$ & 0.134 \\
Individualistic tendencies & 0.273 & $0.697 *$ & 0.055 \\
Politics among members & 0.122 & $0.680^{*}$ & 0.111 \\
Instability of government policy & 0.099 & 0.023 & 0.275 \\
High fragmentation of land holdings & $0.471^{*}$ & 0.303 & 0.020 \\
Inadequate training opportunities & $0.843^{*}$ & 0.174 & 0.060 \\
Inadequate extension programmes & $0.563^{*}$ & 0.334 & 0.304 \\
Inadequate public awareness & $0.536^{*}$ & 0.259 & 0.375 \\
Inability to repay loans & 0.426 & 0.413 & 0.377 \\
Unavailability of collateral for & 0.338 & 0.457 & 0.400 \\
securing loans & & & \\
Unnecessary bureaucracy for & 0.327 & 0.495 & 0.462 \\
obtaining loans & 0.188 & 0.279 & $0.523^{*}$ \\
Insufficient number of members & 0.137 & 0.253 & $0.773^{*}$ \\
Lack of funds & 0.164 & 0.085 & $0.752^{*}$ \\
Untimely provision of farm inputs & & & \\
Inability of government to subsidize & 0.155 & 0.178 & $0.805^{*}$ \\
farm inputs & & & \\
\hline & & & \\
\hline
\end{tabular}

Factor 1: Institutional factors

Factor 2: Funding factors

Factor 3: Input-related factors

\section{Conclusion and Recommendations}

The study indicates that a greater percentage of the respondents were middle-aged, males, married and literate, having acquired one form of education or the other. Major sources of funds were savings and contributions, cooperatives and relations, among others. The study concludes that access to information, increases members' income and food security, high productivity/ increase in output, easy access to loan facilities, improved market competition and expanded market opportunities, pulling of resources together, easy access to credit facilities, greater access to farm inputs, availability of labour were benefits of cooperative society. However, the respondents' performances were hampered by institutional, funding and input-related factors.

The study recommends that there is need for timely provision of farm inputs for the farmers in order to increase productivity for sustainable agriculture. Adequate awareness campaign is needed in ensuring that farmers' become members of cooperative society so as to pull their resources together for greater productivity.

\section{References}

[1] International Cooperative Alliance ( ICA) (2010). Blue print for a cooperative decade. Geneva: ICA.

[2] Nweze, N. J. (2002). Rural development in Nigeria: Past approaches, emerging issues and strategies for the future. Nigerian Journal of Cooperative Studies, 2 (1), 73-89.

[3] Onuoha, E. (2002). A critique of the drafts of cooperative policy for Nigeria. Nigeria Journal of Cooperative Studies, 2 (1), pp. 10-17.

[4] Ebonyi, V. and Jimoh, O. B. (2002). Cooperative movements: $A$ way out of poverty. Longman Publishers, pp. 9-10.

[5] Ibitoye, S, J. (2012). Survey of the performance of agricultural cooperative societies in Kogi state, Nigeria. European Scientific Journal, 8(28), pp. 98-114.

[6] Borgens, S. O. (2001). Identification as a Trust-generating Mechanism in Cooperatives. Annual Publication of Cooperative Economics.

[7] Birchall, J. (2004). Cooperative and the Millennium Development Goals. Geneva: International Labour Office.

[8] Ibrahim, Y. (2001). Basic aspects of cooperative studies. Kano: Munawwar Books International.

[9] Baarda, J. (2004). Outside equity: Obligation, tradeoffs fundamental cooperative character selected paper at the NCERA-194 2004 Annual Meeting, November $2^{\text {nd }} 2004$.

[10] Flannery, M. J. (1994). An Economic Evaluation of credit unions in the United States. Federal Reserve Bank of Boston. Research Report, No. 54.

[11] Baarda, J. (2006). Current issues in cooperative finance and governance: Background and discussion paper. Washington D. C. USA, Rural Development, Cooperatives programme.

[12] Muhammad, S. H. (2014). The role of cooperative organizations in rural community development in Nigeria: Prospects and challenges. Academic Research International, 5(3), pp. 189-197.

[13] National Population Commission (NPC) (2006). Report of the 2006 Census. Abuja, Nigeria.

[14] Ajani, E. N. (2012). Occupational diversification by rural women in Anambra state, Nigeria. Lambert Academic Publishing, Germany, p. 92. 
[15] Ajani, E. N. and Agwu, A. E. (2012). Information communication technology needs of small-scale farmers in Anambra State, Nigeria. Journal of Agricultural and Food Information, 13:2, pp. 144-156.

[16] Nnadozie, A. K. O, Oyediran, A. G, Njoku, I. A and Okoli, K. C. (2015). Nigerian Agricultural Cooperatives and Rural Development in Ivo L. G. A., Ebonyi State, Nigeria. Global Journal of Management and Business Research, 15 (4), pp. 34-43.

[17] Ajani, E. N. (2013). Constraints to effective use of Information Communication Technologies (ICTs) among small-scale farmers in Anambra State, Nigeria. International Journal of Agricultural Science, Research and Technology, 2 (3), pp. 117-122.

[18] Mbah, E. N., Ezeano, C. I. and Onwusika, A. I. (2017).
Assessment of challenges faced by rural youths in family farming in Benue State, Nigeria: Issues for consideration. International Journal of Interdisciplinary Research and Innovations, 5 (2), pp. 7-15.

[19] Onogwu, G. O. and Arene, C. J. (2007). Effects of lending of formal and informal micro-finance. institutions on Access to Agricultural credit in Nigeria. Journal of Rural Development, 26 (2), pp. 177-187.

[20] Ekong, E. E. (2010). An Introduction to Rural Sociology. Dove Educational Publishers, Uyo, Nigeria, p. 251.

[21] Nweze, N. J. (2003). Cooperative promotion in rural communities: The project approach. Nigerian Journal of Cooperative Studies, 2 (2), 73-86.

[22] Ebonyi, V. and Jimoh, O. B. (2002). Cooperative movements: A way out of poverty. Longman Publishers, pp. 9-10. 